\title{
OBTAINING AND STABILIZATION PROPERTIES OF NANOSIZED SILICA(IV) OXIDE HYDROPHOBIZED BY 50\%
}

\author{
Y. Kashyrina, A. Muratov, O. Miroshnikov, A. Marinin, G. Sokolsky \\ National University of Food Technologies
}

\begin{tabular}{l} 
Key words: \\
Pickering emulsion \\
Nanoparticles \\
Hydrophobic silica \\
Emulsions \\
Cream \\
\hline \multicolumn{1}{c}{ Article history: } \\
Received 16.05.2018 \\
Received in revised form \\
08.06.2018 \\
Accepted 19.06.2018
\end{tabular}

Corresponding author:

Y. Kashyrina

E-mail:

Yasya.loba@gmail.com

\begin{abstract}
Emulsifiers are necessary components for preparation of important food and cosmetic emulsions. Among them prevalence was gained by solid emulsifiers, so-called Pickering's emulsifiers, and the phenomenon has received the name of Pickering's stabilization. The conditions of food and cosmetic emulsions' stabilization due to Pickering's effect on a number of model systems were studied checking possibilities of theoretical prediction of conditions of the most effective emulsions' stabilization. The model food and cosmetic emulsions with solid nanoparticles of silica, which received by heat treatment of the hydrophobic silicon dioxide at the different conditions have been considered.

The subject of research was conditions of emulsions' stabilization by Pickering's nanoparticles. Searching for new emulsifier was made due to such reasons: emulsifier has to be cheap (as it gives essential contribution to the general cost value of finished goods at insignificant their concentration), available, harmless and, certainly, effectively stabilize emulsion's systems, reducing liquid-liquid interphase boundary energy. We have chosen the modified silicon dioxide which is inexpensive, available material, that is manufactured in Ukraine (Orisil M-200) and which was previously thermally processed for the purpose of decrease of hydrophobic groups' part on the surface and increase its stabilizing action. Degree of hydrophobicity of surface was determined by differential thermal and thermogravimetric analysis, and emulsifier was got from initial hydrophobic silica in the muffle furnace at certain temperature. Determination of the sizes of emulsifier's initial sample and after calcining was carried out by the dynamic light scattering method (Malvern Zetasizer Nano ZS). It was established that the optimum temperature and time, at which emulsifier with the best stability action is formed, are as follows: $600^{\circ} \mathrm{C}$ and 1 hour, respectively.
\end{abstract}

DOI: $10.24263 / 2225-2924-2018-24-3-29$ 


\title{
ОТРИМАННЯ ТА СТАБІЛІЗАЦІЙНІ ВЛАСТИВОСТІ НАНОРОЗМІРНОГО СИЛІЦІЙ(IV) ОКСИДУ, ГІДРОФОБІЗОВАНОГО НА $50 \%$
}

\author{
Я.О. Каширіна, О.С. Муратов, О.М. Мірошников, А.І. Маринін, \\ Г.В. Сокольський \\ Національний університет харчових технологій
}

Емульгатори є необхідною складовою приготування важливих харчових $i$ косметичних емульсій. Серед них інтерес викликають тверді нанорозмірні емульгатори Пікерінга, а саме явище отримало назву стабілізаиії за Пікерінгом. У статті досліджено умови стабілізачії харчових і косметичних емульсій за Пікерінгом на прикладах декількох модельних систем і перевірено можливості теоретичного передбачення умов найбільш ефективної стабілізаиії емульсій. Розглянуто модельні харчові та косметичні емульсії $з$ введеними твердими наночастинками кремнезему, отриманих термічною обробкою гідрофобного кремнезему при різних режимах.

Предметом дослідження є умови стабілізаиії емульсій твердими наночастинками за Пікерінгом. Пошук нового емульгатора відбувався з огляду на такі міркування: емульгатор має бути недорогим (оскільки при незначній своій концентраиії він дає суттєвий внесок у загальну собівартість готової продукиії), доступним, нешкідливим та, зрозуміло, ефективно стабілізувати емульсійні системи, зменшуючи поверхневий натяг на межі поділу фаз рідина-рідина. Нами був обраний гідрофобізований кремнезем, який є недорогим $і$ доступним, виробляється в Україні (Орисил М-200), і який попередньо термічно обробили з метою зменшення частки гідрофобних груп на поверхні та збільшення його стабілізувальної дії. Контроль ступеня гідрофобності поверхні виконували методом дериватографії, а сам емульгатор отримувався прожарюванням вихідного гідрофобного кремнезему у муфельній печі при визначеній температурі. Визначення розмірів вихідного й термообробленого зразку проводилося методом динамічного розсіювання світла (Malvern Zetasizer Nano ZS). Встановлено, щя оптилальна температура та час, при яких утворюється емульгатор з найкрамою стабільністю готової емульсії, складає $600^{\circ} \mathrm{C} \mathrm{ma} 1$ година відповідно.

Ключові слова: емульсії Пікерінга, наночастинки, гідрофобізований кремнезем, емульсії, крем.

Постановка проблеми. Емульгатори $є$ одними 3 найпоширеніших добавок до харчових продуктів, які додають 3 метою створення й стабілізації емульсій та інших харчових дисперсних систем. Це стандартний інгредієнт майонезу та інших готових соусів, маргаринів і спредів, вершкового масла, шоколаду, морозива. Емульгатори визначають консистенцію харчового продукту, його пластичні властивості та в'язкість.

Кремнезем отримав поширення як засіб проти злежування порошків, наприклад, при виробництві сипучих приправ для снеків. До переваг слід віднести його низьку собівартість і фізіологічну інертність, тобто у нього 
немає протипоказань щодо його дії на органи шлунково-кишкового тракту. Крім цього, кремнезем може використовуватися як твердий стабілізатор в емульсіях (явище стабілізації Пікерінга), проте найкращим чином після певного модифікування [1].

У попередньому нашому дослідженні [2] розглянуто математичну модель i харчові й косметичні системи, в яких відбувається стабілізація емульсій за Пікерінгом твердими наночастинками різної природи. Встановлено, що найбільшою стабілізувальною здатністю характеризуються частинки $\mathrm{SiO}_{2}$, в яких 50\% поверхні зайнято гідрофобними групами. Перевірити результати теоретичного моделювання [2] експериментально було завданням цієї статті, зокрема провести дослідження властивостей твердих емульгаторів 3 нанорозмірними частинками, здатності емульсій до стабілізації наночастинками, в тому числі частково гідрофобізованого аеросилу; оцінити можливості практичного використання одержаних результатів у технологіях харчових продуктів i косметичних засобів.

Мета статті: експериментально дослідити умови стабілізації харчових i косметичних емульсій за ефектом Пікерінга на прикладах декількох модельних систем і перевірити можливості теоретичного передбачення [2] умов найбільш ефективної стабілізації емульсій.

Матеріали і методи. Об'єктами дослідження були обрані модельні харчові та косметичні емульсії 3 введеними твердими наночастинками кремнеземів, отриманих термічною обробкою модифікованого кремнезему при різних режимах. Предметом дослідження є умови стабілізації емульсій твердими наночастинками за Пікерінгом.

В експериментальному дослідженні була використана льняна олія нерафінована та недезодорована першого холодного віджиму виробництва ТОВ «Агросільпром, Україна. Зразки гідрофобізованого Орисилу марки М-200 (ТУ 31695418-002-2003) витримували 1 годину на повітрі при температурах $200,450,600^{\circ} \mathrm{C}$ для видалення гідрофобних груп з поверхні. Одержані тверді зразки використовували для стабілізації емульсій. Маса речовини твердого емульгатора складала близько 80 мг на 40 мл емульсії. Для проведення термообробки та приготування емульсій залучали також гідрогель метилкремнієвої кислоти «Ентеросгель» (ПрАТ «Креома-Фарм»).

Розмір і дзета-потенціал частинок визначали, використовуючи $1 \%$ суспензії порошку $\mathrm{SiO}_{2}$ в олії льону. Усі зразки піддавалися ультразвуковій диспергації (протягом 5 хвилин). Розподіл за розмірами частинок і дзета-потенціал визначалися на приладі Malvern Nano Zetasizer ZS (Malvern Instruments Ltd., Великобританія) методом динамічного розсіювання світла (DLS). Відповідні параметри (в'язкість, показник поглинання та показник заломлення) були взяті 3 літератури. Для $\mathrm{SiO}_{2}$ : коефіцієнт поглинання складає 0,1 , показник заломлення 2,89; для води: в'язкість $1,0031 \cdot 10^{-4}$ Па·с, показник заломлення 1,33; для льняної олії: в'язкість $33,1 \cdot 10^{-4}$ Па·с, показник заломлення 1,48 ,

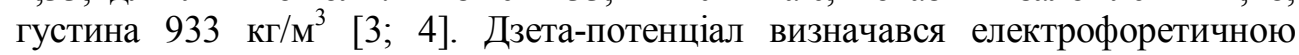
рухливістю частинок за рівнянням Смолуховського.

Готували зразки емульсії першого та другого типів зі співвідношеннями об’ємів рідких фаз вода-олія (1:1) та (1:3), відповідно, загальним об’ємом 40 мл. 
Використовували ультразвуковий метод диспергації на приладі BANDELIN UW 2070.

Деякі зразки аналізували методом ІЧ-спектроскопії для підтвердження гідрофобізації, яке здійснювали на інфрачервоному Фур'є спектрометрі ФСМ12013 комп’ютерним інтерфейсом, в області довжини хвиль $400-4000 \mathrm{~cm}^{-1}$. Зразки ретельно змішували з порошком $\mathrm{KBr}$ у співвідношенні 1:300 і пресували у прозорі таблетки - прямокутні пластинки розміром $5 \cdot 26 \mathrm{mм}^{2}$. Термогравіметричні дослідження виконували на модернізованому в ІТТФ НАН України дериватографі Q-1000 виробництва фірми МОМ (Угорщина). Умови проведення термічного аналізу: швидкість нагрівання зразка $7,36 \mathrm{~K} \cdot \mathrm{xв}^{-1}$; температурний інтервал - від кімнатної до $1000^{\circ} \mathrm{C}$; шкала ваг - 50 мг.

Підбір власної методики одержання емульсій за Пікерінгом виконували на основі даних [5; 6]. Метод отримання емульсій Пікерінга включав вибір певного співвідношення рідких фаз з однією концентрацією емульгатора, перемішування базовим гомогенізатором: ультразвуковим (потужністю $500 \mathrm{BT}$ протягом 2 хв) або механічним (6000 об. $\cdot \mathrm{xB}^{-1}$ протягом 60 с при $\left.25^{\circ} \mathrm{C}\right)$ у послідовності, що визначалася кращою змочуваністю твердого емульгатора 3 однією 3 рідких фаз. Індекс стабільності отриманих емульсій Пікерінга визначався за зміною об’ємної частки фаз емульсії при відстоюванні протягом 30 хв, 4 діб і 2 тижнів. Тип емульсії перевірявся за допомогою крапельного тесту.

Результати і обговорення. Термічна обробка Орисилу. Гідрофобізований кремнезем знайшов широке застосування у фармації та інших галузях завдяки своїм унікальним властивостям щодо закріплення функціональних поверхневих груп різної природи. Нами обрано марку Орисил М-200 як оптимальну 3 точки зору розміру наночастинок i питомою поверхнею. Проведено термогравіметричне дослідження вихідного зразка Орисилу М200 (рис. 1). За результатами аналізу кривої ДТА (рис. 1) видно, що спочатку відбуваються ендотермічні процеси десорбції води: фізично сорбованої (з ДТА-максимумом при $100^{\circ} \mathrm{C}$ ), хімічно сорбованої (при $200^{\circ} \mathrm{C}$ ). Інтенсивний максимум ендоефекту при $720^{\circ} \mathrm{C}$ з плечем при $590^{\circ} \mathrm{C}$ відповідає процесам деструкції за участю гідрофобних груп поверхні Орисилу з поступовим перетворенням силанольних груп у силоксанові при температурах $350-950^{\circ} \mathrm{C}$. Аналіз ТГ і ДТГ залежностей показує відсутність чітко виражених ефектів, що, можливо, пов'язано з аморфізованістю матеріалу.

Відповідно до даних [7] щеплені метоксильні групи стійкі при нагріванні на повітрі до $170^{\circ} \mathrm{C}$, а у вакуумі - до $430^{\circ} \mathrm{C}$. При нагріванні до $600^{\circ} \mathrm{C}$ вони повільно розкладаються з утворенням силанових груп:

$$
\equiv \mathrm{SiOCH}_{3} \rightarrow \equiv \mathrm{SiH}+\mathrm{HCHO}
$$

відповідно до [8], де автори спостерігали перехід від гідрофобного до гідрофільного стану. Це дало змогу зробити висновок про утворення на поверхні силанольних груп. На нашу думку, це може узгоджуватися 3 даними Г.В. Лісічкина за умови подальшого окиснення отриманої силанової групи киснем повітря. Отже, загальну реакцію такої термодеструкції поверхні гідрофобізованого кремнезему можна записати узагальненою формулою:

$$
2 \equiv \mathrm{SiOCH}_{3}+3 \mathrm{O}_{2} \rightarrow \equiv \mathrm{Si}-\mathrm{O}-\mathrm{Si} \equiv+2 \mathrm{CO}_{2}+3 \mathrm{H}_{2} \mathrm{O} \text {. }
$$




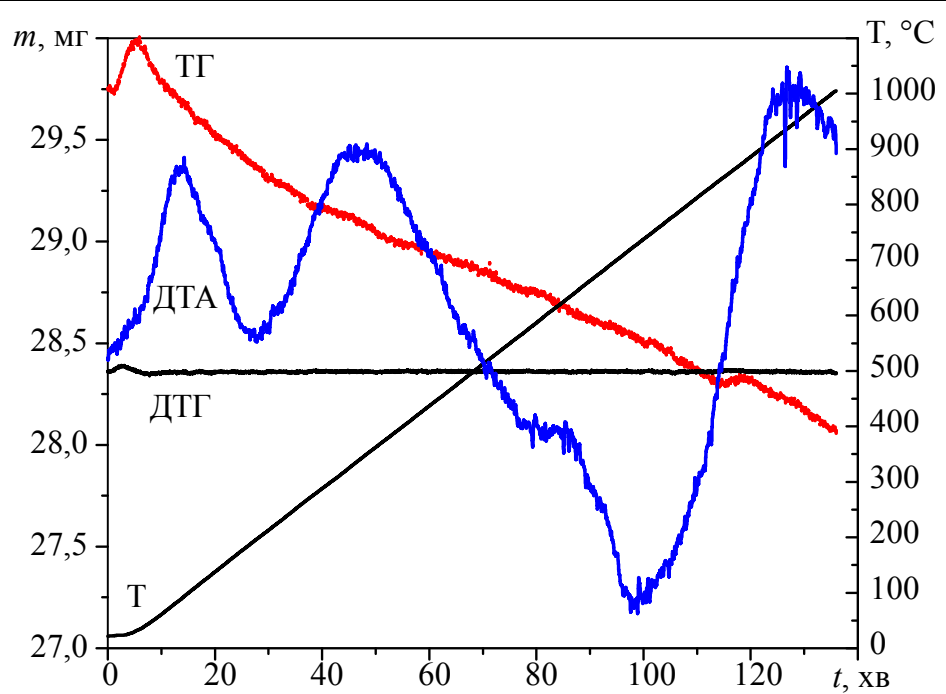

Рис. 1. Дериватограма вихідного зразку Орисилу М-200, швидкість нагрівання зразка $7,36 \mathrm{~K} \cdot \mathbf{x B}^{-1}$

Відповідно до результатів термогравіметричного аналізу при виборі режиму термообробки виходили 3 таких міркувань: нагрівання вихідного кремнезему при $200^{\circ} \mathrm{C}$ видаляє фізично сорбовану воду; при прожарюванні до $450^{\circ} \mathrm{C}$ силанольний покрив кремнезему значною мірою видаляється і концентрація поверхневих гідроксильних груп такого зразка знижується до $\sim 3$ мкмоль $\cdot \mathrm{M}^{-2}$; концентрація поверхневих гідроксильних груп повністю гідроксильованого аморфного кремнезему становить $\sim 8$ мкмоль $\cdot \mathrm{M}^{-2}[9 ; 10]$.

За даними термогравіметричного аналізу встановлено, що втрата маси за ефектом ДТА у діапазоні $350-950^{\circ} \mathrm{C}$ (рис. 1) відповідає концентрації гідрофобних груп 1,19 ммоль $\cdot \Gamma^{-1}$.

Ураховуючи майже лінійний вигляд кривої ТГ в області температур 350$950^{\circ} \mathrm{C}$, що відповідає перетворенням гідрофобних груп поверхні зразка, можна використати ефект ДТА для встановлення температури, де буде реалізовуватися ступінь гідрофобності в 50\%, що має місце при температурі приблизно середини області розкладу на ТГ, тобто при $600^{\circ} \mathrm{C}$.

Відповідно до ТУ У 24.1-31695418-002:2008, площа поверхні Орисилу М200 , заповненої цими групами, дорівнює $200 \mathrm{~m}^{2}{ }^{\cdot} \Gamma^{-1}$, що, враховуючи вихідну концентрацію поверхневих груп, відповідає значенню 1,6 ммоль $\cdot \Gamma^{-1}$ та відрізняється від експериментальної у межах похибки. Таким чином, поверхня вихідного Орисилу повністю заповнена гідрофобними групами, i, як наслідок, для отримання необхідного 50\%-гідрофільного кремнезему необхідно його нагріти до температури $600^{\circ} \mathrm{C}$ відповідно до рис. 1 i наших розрахунків.

Для перевірки цього припущення обирали три температури, при якій відпалювався зразок: 200, 400 та $600^{\circ} \mathrm{C}$ протягом 0,5 та 1 год. Час підбирався 3 метою підбору умов, коли взаємодіє весь об'єм матеріалу при його прокалюванні у печі. 
Процес диспергаціï. Режим диспергації підбирали експериментальним шляхом. Варіювалися такі параметри, як час і потужність ультразвукової обробки. На підставі попередніх дослідів було обрано час 5 хв при потужності $80 \%$ з метою спостереження змін у стабільності емульсій, стабілізованих наночастинками кремнезему 3 різним ступенем гідрофобізації. Стабільність емульсій оцінювали в часі за розшаруванням іiі компонентів (рис. 2). 3 рис. 2 видно, що найменше розшарування та найкраща стабілізація характерні для зразка, термообробленого при $600^{\circ} \mathrm{C}$ протягом 1 години. Незначна відмінність зразка 3 , ймовірно, пояснюється неповним видаленням фізично адсорбованої води та гідроксогруп водночас із частковою деструкцією гідрофобних груп, бо час обробки був мінімальним і складав 30 хв при $600^{\circ} \mathrm{C}$.

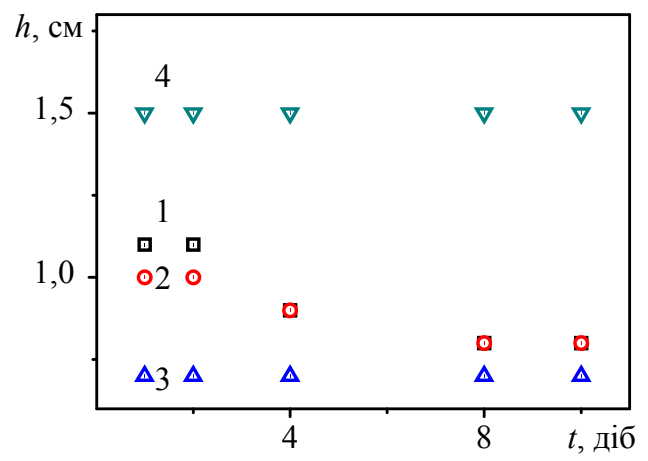

Рис. 2. Залежність висоти шару жирової фази прямої емульсії від часу: 1 - вихідний зразок М-200; 2 - термооброблені при $450^{\circ} \mathrm{C} ; 3$ - при $600^{\circ} \mathrm{C}\left(0,5\right.$ год); 4 - при $600^{\circ} \mathrm{C}(1$ год)

Дослідження розміру частинок у льняній олії показало, що внаслідок відпалу вихідних гідрофобних зразків при $600^{\circ} \mathrm{C}$ спостерігається їх укрупнення (рис. 3 -4), що може пояснюватися взаємодією не лише силанольних груп на одній поверхні, а й «зшиванням» між поверхневими групами, які належать до різних частинок, закріплюючи таким чином їх агрегацію. Спостерігається звуження розподілу за розміром після термообробки зразка Орисилу при $600^{\circ} \mathrm{C}$.

Statistics Graph (6 measurements)

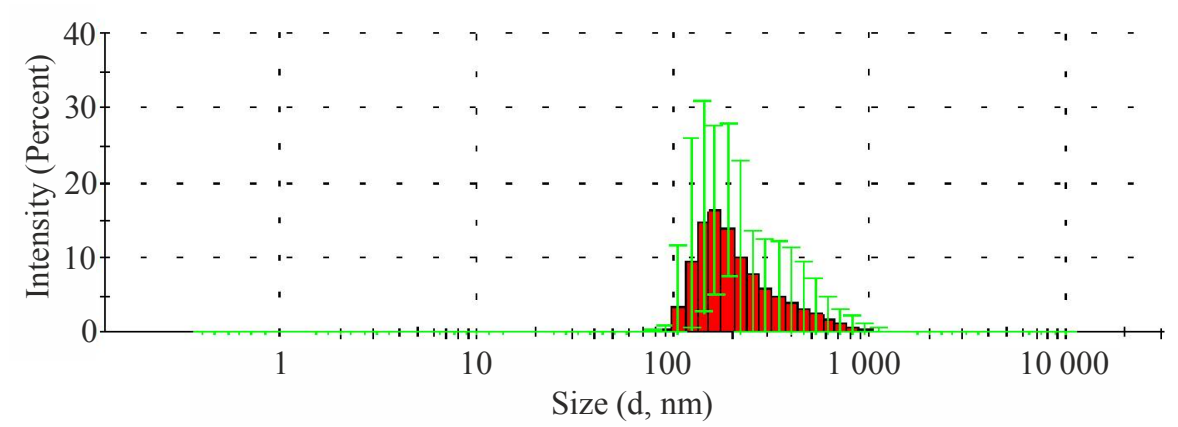

Рис. 3. Розподіл частинок за розмірами для вихідного Орисилу М-200, диспергованого у льняній олії 
Statistics Graph (5 measurements)

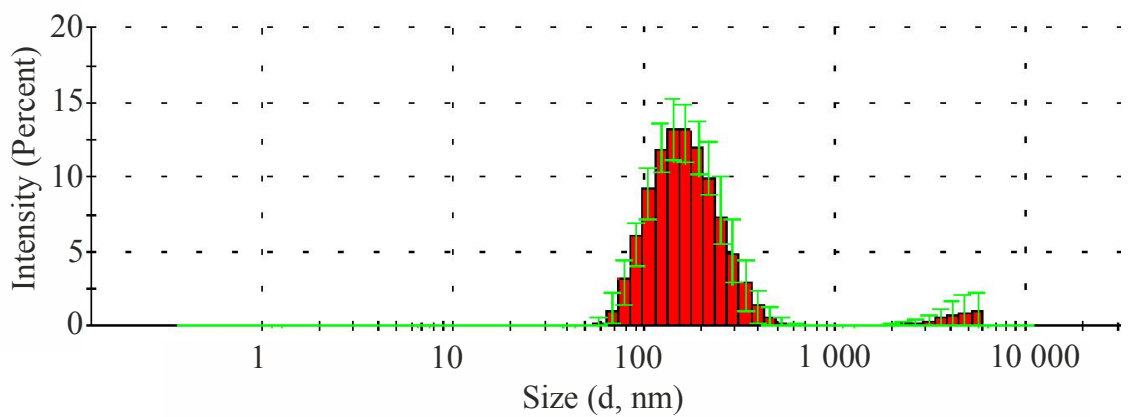

Рис. 4. Розподіл частинок за розмірами для термообробленого Орисилу М-200 при 600 ${ }^{\circ} \mathrm{C}$ протягом 1 год, диспергованого у льняній олії

Гідрофобні та кислотно-основні властивості поверхні твердих наномаmеріалів. ІЧ-спектроскопічне дослідження здійснювали для виявлення алкільних груп поверхні кремнезему та коливань різних типів води, в тому числі ОН-груп від силанольних груп на поверхні кремнезему. Результати ІЧ-спектроскопічного дослідження наведено на рис. 5-6.

Підтверджено наявність алкильних груп у досліджених зразках за валентними коливаннями зв’ язку С-Н у діапазоні $2800-3000 \mathrm{~cm}^{-1}$.

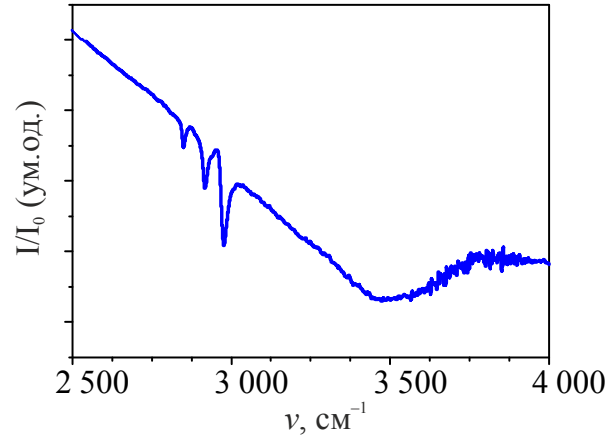

Рис. 5. ІЧ-спектр зразка «Ентеросгелю» у діапазоні $2500-4000 \mathrm{~cm}^{-1}$

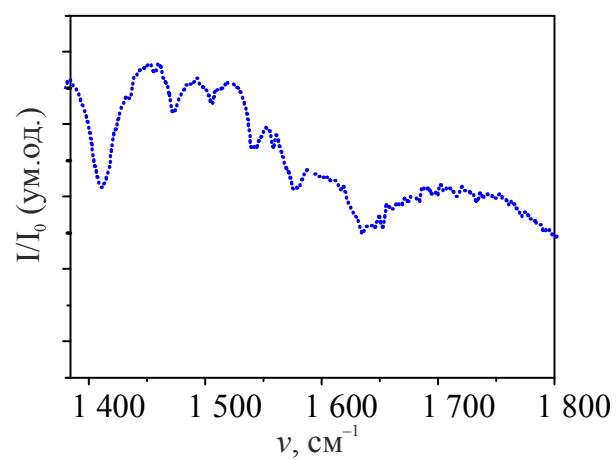

Рис. 6. ІЧ-спектр зразка «Ентеросгелю» у діапазоні $1380-1800 \mathrm{~cm}^{-1}$

Практичне використання отриманого емульгатора у виробництві емульсійного крему. Запропонований емульгатор успішно використаний для розробки рецептури емульсійного крему з екстрактом Amanita muscaria, де як дисперсна фаза виступала соняшникова олія, дисперсійне середовище - дистильована вода. Підтведження того, що емульсія є прямою, надав емульсійний тест, де під мікроскопом видно крапельки олії, що розподілені у забарвленій водорозчинним барвником воді. Рецептура запропонованого крему наведена в таблиці.

Таблиця. Рецептура оптимального емульсійного крему з екстрактом Amanita muscaria

\begin{tabular}{|c|c|c|}
\hline Назва & Маса компонента в грамах & Вміст у $\%$ \\
\hline 1 & 2 & 3 \\
\hline Олія соняшникова & 33,5 & 37,10 \\
\hline
\end{tabular}




\begin{tabular}{|c|c|c|}
\hline \multicolumn{2}{c}{} & \multicolumn{2}{c}{ Продовження таблииі } \\
\hline 1 & 2 & 3 \\
\hline Віск бджолиний жовтий,соти & 3,0 & 3,3 \\
\hline Екстракт Атапіta тизсанia & 2,3 & 2,55 \\
\hline Вода дистильована & 31,2 & 34,6 \\
\hline Парфум «Акація» & 0,2 & 0,2 \\
\hline Какао масло & 6,9 & 7,6 \\
\hline Кокосове масло & 4,5 & 5,0 \\
\hline Розчин натрію тетраборату & 0,4 & 0,4 \\
\hline Гідролізат протеїнів шовку & 3,8 & 4,2 \\
\hline Кремнезем & 1,8 & 2,0 \\
\hline Гліцерин & 2,3 & 2,55 \\
\hline Барвник харчовий, блакитний & 0,3 & 0,3 \\
\hline Запашка «Тирамісу» & 0,1 & 0,1 \\
\hline Всього & 90,3 & 100 \\
\hline
\end{tabular}

Результати дослідів 3 отримання емульсійного крему показали, що утворилась однорідна емульсія, де було помітне забарвлення крапель водної фази, оскільки харчовий барвник краще розчинний у воді. Всі компоненти добре розчинились у відповідних фазах та утворили емульсію, яка не розшарувалась. Консистенція крему за органолептичними показниками відповідає вимогам до емульсійних кремів. Тож утворений емульсійний крем свідчить про коректність підібраних компонентів, та їх масових співвідношень між собою в заданій рецептурі. Оптимальний вміст кремнезему становить близько 2 г на 100 г продукту.

\section{Висновки}

1. Запропоновано використовувати для перевірки ефекту стабілізації емульсій за Пікерінгом наночастинки гідрофобізованого кремензему Орисилу (M-200), відпалені при різних температурах. За нашими даними математичного моделювання 50\% гідрофільний кремнезем має оптимальні властивості, що знайшло експериментальне підтвердження, враховуючи повне видалення органіки 3 поверхні кремнезему до $1000^{\circ} \mathrm{C}$ та найкращі параметри стабільності в зразка Орисилу М-200, відпаленого при $600^{\circ} \mathrm{C}$.

2. Методом термогравіметрії обгрунтовано режим термообробки зразків Орисилу М-200, а методом динамічного розсіювання світла показано, що відпал закономірно призводить до спікання частинок, проте такий процес $\epsilon$ несуттєвим і не погіршує стабілізаційні властивості кремнезему, підтверджено наявність алкільних груп у зразках твердого стабілізатора методом ІЧ спектроскопії.

3. Опрацьовано метод ультразвукової та механічної диспергації для одержання емульсії вода - льняна олія з використанням модифікованого кремнезему Орисилу марки М-200 як стабілізатора у порівнянні з системою без стабілізатора. Підтверджено, що найкращими стабілізувальними властивостями характеризується кремнезем, що попередньо відпалений при $600^{\circ} \mathrm{C}$ протягом 1 години з метою часткового зменшення гідрофобності поверхні. 


\section{Лiтература}

1. Binks B.P. Solid Wettability from Surface Energy Components: Relevance to Pickering Emulsions / B.P. Binks, J.H. Clint // Langmuir. - 2002. - V. 18, issue 4. - P. 1270-1273.

2. Mathematical modeling of Pickering emulsions stabilization process by solid nanoparticles / Y.Kashyrina, O. Muratov, G. Sokolskyi, O. Miroshnikov // Ukrainian Food Journal. 2017. — № 6. - P. 524-533.

3. Thomas A. Fats and Fatty Oils / A. Thomas, B. Matthäus, H. Fiebig // Ullmann's Encyclopedia of Industrial Chemistry. - Weinheim: Wiley-VCH, 2015. — P. 1-84.

4. Shahidi F. Bailey's Industrial Oil and Fat Products, 6th Edition / F. Shahidi. - Hoboken, N.J. : John Wiley \& Sons, 2005. - 3687 c.

5. Frelichowska J. Pickering emulsions with bare silica / J. Frelichowska, M. Bolzinger, Y. Chevalier. // Colloids and Surfaces A: Physicochem. Eng. Aspects. — 2009. — \# 343. — P. $70-74$.

6. Ossenkamp G.C. New Approaches to Surface-Alkoxylated Silica with Increased Hydrolytic Stability / G.C. Ossenkamp, T. Kemmitt, J.H. Johnston // Chem. Mater. — 2001. — \# 13. P. 3975-3980.

7. Химия привитых поверхностных соединений / Под ред. Г.В. Лисичкина. - Москва : ФИЗМАТЛИТ, 2003. - $592 \mathrm{c}$.

8. Effect of solvent exchanging process on the preparation of the hydrophobic silica aerogels by ambient pressure drying method using sodium silicate precursor / A.P.Rao, A.V. Rao, G.M. Pajonk, P.M. Shewale. // Journal of Materials Science. - 2007. — \# 42. — P. 8418-8425.

9. Получение прямых эмульсий, стабилизированных наночастицами $\mathrm{SiO}_{2}$ / Д.А. Быданов, К.В. Паламарчук, М.Ю. Королева, Е.В. Юртов. // Успехи в химии и химической технологии. - 2015. - № 29. - С. 102-104.

10. Zuravlev L.T. Surface concentration of hydroxyl groups on amorphous silicas having different specific surface areas / L.T. Zuravlev, A.V. Kiselev // International simposium: International union of pure and applied chemistry. Butterworths. London. — 1969. - P. 155-160. 